\title{
Genetic Diversity Among some Egyptian Bread Wheat Cultivars Based on Morphological Characters and SSR Markers
}

Feltaous, Y.M.

Wheat Research Department, Field Crops Research Institute, Agricultural Research Center, Giza, Egypt. Email: feltaous80@yahoo.com

Received on: 24/12/2019

Accepted for publication on: 13/1/2020

\begin{abstract}
:
The fundamental objective of any successful breeding program is releasing divergent cultivars adapted to every region's requirements all over the country. The traditional method for estimating genetic diversity is morphological characterization. The polymorphism based DNA characterization recently has been emerged as a suitable tool in estimating genetic diversity. The present study included 14 Egyptian bread wheat cultivars. This investigation conducted at Shandaweel Agricultural Research Station, Agricultural Research Center, Egypt during two growing seasons 2016/2017 and 2017/2018. The genetic diversity estimated based on 17 morphological characters as well as 21 microsatellite markers i.e. SSR markers. The phenotypic results indicated significant and highly significant differences among the studied cultivars. Based on the morphological data the principal component analysis (PCA) computed where it revealed that the first principal component (PC1) and the second principal component (PC2), explained $49.31 \%$ of the total variability. PC1 and PC2 used to construct genotype by trait biplot (GT biplot) to group the cultivars into different groups. In the same context, the genetic variability estimated using microsatellite markers; the results revealed that high polymorphism information content (PIC) and high marker index (MI) were found. High variation were found in A and B genomes rather than D genome. Genetic similarity matrix (Jaccard coefficient) was computed based on the presence and absence of SSR marker bands. Similarity matrix showed that the highest similarity (0.620) was found between Giza 171 and Giza 168 cultivars and the lowest similarity (0.250) was found between Shandaweel 1 and Misr 3 cultivars. The dendrogram constructed based on similarity matrix and it clustered the cultivars into three main groups. The correlation coefficient (Pearson coefficient) between individual characters and markers show strong, positive, and significant correlation between specific markers and particular characters suggesting that each of these specific markers is a candidate linked marker for this particular character to be used in Markers Assisted Selection (MAS). The similarity among cultivars based on morphological characters showed a narrow range, whereas the similarity among cultivars based on SSR showed a broad range. The similarity based SSR markers was more accurate and informative than morphological characters basis. This investigation reveals that SSR markers are well utilized in estimating genetic diversity.
\end{abstract}

Keywords: Morphological descriptors, GT biplot, PIC, DNA Polymorphism

Introduction:

Wheat is the most widely cereal grown in the world. It is grown in a wide range of environments. It is the staple food for $35 \%$ of the world population particularly in developing 
countries like Egypt. Where, it is grown throughout the country in Nile valley, as well as, in the newly reclaimed areas. It is the most important food crop for Egyptian, its cultivated area in 2017 was 1.34 Million hectares (equal to 3.20 Million Feddan; feddan $=2.38$ hectares) producing 8.80 million tonnes (FAO STAT, 2017a). It represents almost $10 \%$ of the total value of agricultural production and about $20 \%$ of all agricultural imports. Egypt is the largest wheat consumer where the plan for wheat procurement is important 3.7 million tonnes (FAOSTAT 2017b). For all these aspects, wheat plays a vital role in Egypt's economy as a strategic crop.

The genetic diversity is an important goal for any successful breeding program. The diversified cultivars, definitely with high yielding potentiality, are very important to adapt specific region conditions and challenges i.e. biotic and abiotic stresses. In this context, the conventional methods used to characterize and estimate variability between cultivars are based on morphological characterization and phenological observation i.e. distinctness, uniformity, and stability (DUS). The DUS system that was established by UPOV in the year of 1961 (International Union for the Protection of New Varieties) is satisfactory so far. For instance, the morphological characterization of wheat genetic diversity has been extensively studied around the world (Kahrizi et al., 2010; Malik et al., 2013 and Malik et al., 2014). The disadvantages of these conventional methods are limited in number, time consuming, costly, and highly influenced by environmental factors. On the other hand, molecular markers are abundant, easy handling, independent from environmental factors. For all these aspects molecular markers used extensively and took much attention as a useful tool and straight-forward technique in genetic diversity studies. Therefore, characterization based on DNA polymorphism i.e. molecular markers basis is more efficient and accurate. Deploying molecular markers in genetic diversity assessment are used widely in the last two decades for their advantages on morphological characters (Tasnuva et al., 2010; Salem et al., 2015 and Osama et al., 2016).

The microsatellite markers or Simple Sequence Repeats (SSR markers) are one of the most effective and acceptable markers were used widely in identifying genetic variability. It is the most common markers used for establishing genetic interrelationships, diversity, and selection criteria. The merits of SSR i.e. multiallelic, highly polymorphic, codominant inheritance, highly informative, reproducible and easy handling made them widely used in wheat investigation for its advantages. Many investigations in wheat indicated that SSR markers are more polymorphic than RLFP or AFLP and a small number of SSR markers are sufficient to distinguish closely related genotypes (Noli et al., 2008 and Salem et al., 2008). Adoption and implementation of molecular markers characterization in determining genetic variability enable the breeders to assess the interrelationships, classify and characterize a large number of genetic materials even the tightly 
linked. It is more accurate, rapid and reliable (Noli et al., 2008; Zarkti et al., 2010; Malik et al., 2014 and Osama et al., 2016). The utilization of molecular markers as a tool in cultivars identification was suggested by the Working Group on Biochemical and Molecular Techniques (BMT), UPOV 2004.

The objectives of this investigation are utilization of SSR markers in estimating genetic variability compared to traditional methods and find the association between studied characters and specific markers, and imply its benefits in breeding programs.

\section{Materials and Methods:}

\section{Plant materials and morphological characters}

This study conducted at Shandaweel Agricultural Research Station, Agriculture Research Center, Egypt during two growing seasons 2016/17 and 2017/18. This study included 14 Egyptian bread wheat cultivars (Table 1) i.e. Shandaweel 1, Sids 1, Sids12, Sids 13, Sids 14, Giza 168, Giza 171, Misr 2, Misr 3, Sakha 93, Sakha 94, Sakha 95, Gemmiza 11 and Gemmiza 12. The experimental design was RCBD in three replications. Experimental plot consisted of 6 rows, $20 \mathrm{~cm}$ apart, and $3.5 \mathrm{~m}$ long $\left(\right.$ plot area $\left.=4.2 \mathrm{M}^{2}\right)$.

Table 1. The studied Egyptian wheat cultivars and their pedigree.

\begin{tabular}{|c|c|c|c|c|}
\hline No & Cultivar & $\begin{array}{c}\text { Parentage } \\
\end{array}$ & No Cultivar & $\begin{array}{r}\text { Parentage } \\
\end{array}$ \\
\hline 1 & Shandaweel 1 & 1 SITE//MO/4/NAC/TH.AC//3*PVN/3/MIRLO/BUC & \begin{tabular}{|l|l|}
8 & Misr 2 \\
\end{tabular} & SKAUZ/ BAV 92 \\
\hline 2 & Sids 1 & HD2172/Pavon“S”//1158.57/Maya74“S” & 9 Misr 3 & Rolef $07 * 2 /$ Kiriti \\
\hline 3 & Sids 12 & $\begin{array}{l}\text { BUS//7C//ALD/5/MAYA74/ON//1160.147/3/BB/ } \\
\text { GLL/4/CHAT"S"/6/MAYA/VUL//CMH74A.630/4*SX }\end{array}$ & 10 Sakha 93 & Sakha92/TR810328 \\
\hline 4 & Sids 13 & ALmaz 19= Kauz 'S"'//Tsi /snb"'S", & 11 Sakha 94 & Opata/Rayon//Kauz \\
\hline 5 & Sids 14 & Bows "s"/vee"s"// Bows “s"/TSI/Bani Sewef 1 & 12 Sakha 95 & $\begin{array}{l}\text { PASTOR//SITE/MO/3/CHEN/AEGILOPS } \\
\text { SQARROSA(TAUS)//BCN/4/WBLL1 }\end{array}$ \\
\hline 6 & Giza 168 & MIL/BUC// Seri & 13 Gemmiza & $\begin{array}{l}\text { Bow"s"/ Kvz // 7C / Seri 82 /3/ Giza 168 / } \\
\text { Sakha 61 }\end{array}$ \\
\hline 7 & Giza 171 & Gemmeiza9 / Sakha93 & 14 Gemmiza 12 & OTUS/3/SARA/THB//VEE \\
\hline
\end{tabular}

The cultivars under investigation were phenotyped using some morphological characters used for distinctness, uniformity and stability (DUS). The morphological descriptors are 17 characters recorded in all growing stages to assess genetic variability between the cultivars under investigation. Scoring values for each state of selected descriptor were given discrete number value to generate numerical dataset (Table 2).

\section{Molecular markers:}

The molecular marker characterization was carried out at the Labo- ratory of Biotechnology - Department of Genetics, Faculty of Agriculture, Assiut University, Egypt. The genotypic characterization for the studied cultivars was done using 21 SSR markers. Each chromosome represented by one marker covering all wheat genomes. Total genomic DNA extracted from young leaves "two weeks old" for all cultivars under investigation using cetyltrimethyl ammonium bromide procedure (modified CTAB procedure) described by Poresbski et al., 1997. 
Table 2. The morphological characters and its numerical scores in some Egyptian wheat cultivars

\begin{tabular}{|c|c|c|c|c|c|}
\hline Characters & Abbreviation & Descriptors & Characters & Abbreviation & Descriptors \\
\hline Growth habit & G. $\mathrm{H}$ & $\begin{array}{l}1 \text { Erect } \\
3 \text { Semi-erect } \\
5 \text { Intermediate } \\
7 \text { Semi- spreading } \\
9 \text { prostrate }\end{array}$ & Ear waxiness & Ear Wax & $\begin{array}{l}1 \text { Absent } \\
3 \text { Weak } \\
5 \text { Medium } \\
7 \text { Strong } \\
9 \text { Very strong }\end{array}$ \\
\hline $\begin{array}{l}\text { Auricles colora- } \\
\text { tion } \\
\text { (purple pigment) }\end{array}$ & CL. AR & $\begin{array}{|ll|}1 & \text { Absent } \\
5 & \text { Medium } \\
9 & \text { Strong }\end{array}$ & Flag leaf width & F. L. W & $\begin{array}{l}1 \text { Narrow }(<1.5) \\
5 \text { Medium }(1.5-2) \\
9 \text { Broad }(>2.0)\end{array}$ \\
\hline $\begin{array}{l}\text { Flag leaf atti- } \\
\text { tude }\end{array}$ & F. L. AT & $\begin{array}{|ll|}1 & \text { Erect } \\
3 & \text { Semi-erect } \\
5 & \text { drooping } \\
\end{array}$ & 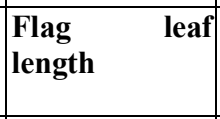 & F. L. L & $\begin{array}{l}1 \text { Short }(<20) \\
5 \text { Medium }(20-30) \\
9 \text { Long }(>30) \\
\end{array}$ \\
\hline $\begin{array}{l}\text { Waxiness of } \\
\text { flag leaf sheath }\end{array}$ & W. SH & $\begin{array}{l}1 \text { Absent } \\
3 \text { Weak } \\
5 \text { Medium } \\
7 \text { Strong } \\
9 \text { Very strong }\end{array}$ & $\begin{array}{l}\text { Leaf blade } \\
\text { waxiness }\end{array}$ & W. BL & $\begin{array}{l}1 \text { Absent } \\
3 \text { Weak } \\
5 \text { Medium } \\
7 \text { Strong } \\
9 \text { Very strong } \\
\end{array}$ \\
\hline $\begin{array}{ll}\text { Waxiness } & \text { of } \\
\text { peduncle } & \end{array}$ & W. Ped & \begin{tabular}{|l}
1 Absent \\
3 Weak \\
5 Medium \\
7 Strong \\
9 Very strong \\
\end{tabular} & $\begin{array}{l}\text { Peduncle } \\
\text { length }\end{array}$ & Ped. L & $\begin{array}{l}1 \text { Short }(<30) \\
5 \text { Medium }(30-50) \\
9 \text { Long }(>50)\end{array}$ \\
\hline $\begin{array}{l}\text { Ear shape in } \\
\text { profile }\end{array}$ & Ear Shape & \begin{tabular}{|ll}
1 & Tapering \\
3 & Parallel sided \\
5 & Semi-clavate \\
7 & Clavate \\
9 & Fusiform \\
\end{tabular} & Ear density & Ear Dens & $\begin{array}{l}1 \text { Very lax } \\
3 \text { Lax } \\
5 \text { Medium } \\
7 \text { Dense } \\
9 \text { Very dense }\end{array}$ \\
\hline $\begin{array}{l}\text { Ear orienta- } \\
\text { tion }\end{array}$ & Ear Orint & $\begin{array}{l}3 \text { Erect } \\
5 \text { Semi-erect } \\
7 \text { Dropping }\end{array}$ & $\begin{array}{l}\text { Hairs of auri- } \\
\text { cles }\end{array}$ & HR. AR & $\begin{array}{l}3 \text { Absent } \\
5 \text { Medium } \\
7 \text { Strong }\end{array}$ \\
\hline Foliage colour & F. CL & $\begin{array}{l}1 \text { Pale green } \\
5 \text { Green } \\
9 \text { dark green }\end{array}$ & $\begin{array}{l}\text { Outer glume } \\
\text { pubescence }\end{array}$ & Out. Gl. Pub & $\begin{array}{l}3 \text { Absent } \\
5 \text { Medium } \\
7 \text { Strong } \\
\end{array}$ \\
\hline Plant height & PL. HT & \begin{tabular}{|l}
1 Very short $(<75 \mathrm{~cm})$ \\
3 Short $(75.1-90 \mathrm{~cm})$ \\
5 Medium $(90.1-105 \mathrm{~cm})$ \\
7 Long $(105.1-120 \mathrm{~cm})$ \\
9 Very Long $(>120 \mathrm{~cm})$ \\
\end{tabular} & & & \\
\hline
\end{tabular}

The studied cultivars are pure culture although five plants per cultivar pooled for DNA isolation to protect extracted DNA from contamination of single seed. RNAase was added to DNA for 30 minutes at 37 $\mathrm{C}^{\circ}$ to remove RNA. DNA quantification was done by spectrophotometer.
Amplification reactions performed, the PCR products loaded to agarose gel and separated by electrophoresis. The amplificon visualized by UV light documentation system. The SSR primers' name, their sequences, chromosomal location, and annealing temperature are presented in Table 3. 
Table 3. SSR primers' names, sequences, chromosomal location, annealing temperature.

\begin{tabular}{|c|c|c|c|c|}
\hline Primer & Forward Primers sequences & reverse Primers sequences & Chr. & An. $\mathrm{C}^{\circ}$ \\
\hline Xgwm33 & 5' GGAGTCACACTTGTTTGTGCA3' & 5' CACTGCACACCTAACTACCTGC3' & $1 \mathrm{~A}$ & $60 \mathrm{C}^{\circ}$ \\
\hline Xgwm18 & $\begin{array}{l}\text { 5' GGTTGCTGAA- } \\
\text { GAACCTTATTTAGG3' }\end{array}$ & $\begin{array}{l}\text { 5' TGGCGCCATGATTGCAT- } \\
\text { TATCTTC3' }\end{array}$ & 1B & $50 \mathrm{C}^{\circ}$ \\
\hline Xgwm458 & 5' TTCGCAATGTTGATTTGGC3' & 5' TTCGCAATGTTGATTTGGC 3' & 1D & $60 \mathrm{C}^{\circ}$ \\
\hline Xgwm95 & 5' GATCAAACACACACCCCTCC3' & 5' AATGCAAAGTGAAAAACCCG3' & $2 \mathrm{~A}$ & $60 \mathrm{C}^{\circ}$ \\
\hline Xgwm111 & 5'GTTGCACGACCTACAAAGCA3' & 5'ATCGCTCACTCACTATCGGG3' & $2 \mathrm{~B}$ & $55 \mathrm{C}^{\circ}$ \\
\hline Xgwm261 & 5' CTCCCTGTACGCCTAAGGC3' & 5' CTCGCGCTACTAGCCATTG3' & $2 \mathrm{D}$ & $55 \mathrm{C}^{\circ}$ \\
\hline Xgwm155 & 5' CAATCATTTCCCCCTCCC3' & 5' AATCATTGGAAATCCATATGCC3' & $3 \mathrm{~A}$ & $60 \mathrm{C}^{\circ}$ \\
\hline Xgwm389 & 5' ATCATGTCGATCTCCTTGACG3' & 5' TGCCATGCACATTAGCAGAT3' & $3 \mathrm{~B}$ & $60 \mathrm{C}^{\circ}$ \\
\hline Xgwm3 & 5' AATATCGCATCACTATCCCA3' & 5' AATATCGCATCACTATCCCA 3' & $3 \mathrm{D}$ & $55 \mathrm{C}^{\circ}$ \\
\hline Xgwm160 & 5' TTCAATTCAGTCTTGGCTTGG3' & 5' CTGCAGGAAAAAAAGTACACCC3' & $4 \mathrm{~A}$ & $55 \mathrm{C}^{\circ}$ \\
\hline Xgwm513 & 5' ATCCGTAGCACCTACTGGTCA3' & 5' GGTCTGTTCATGCCACATTG3' & 4B & $60 \mathrm{C}^{\circ}$ \\
\hline Xgwm165 & 5' TGCAGTGGTCAGATGTTTCC3' & 5' CTTTTCTTTCAGATTGCGCC3' & $4 \mathrm{D}$ & $60 \mathrm{C}^{\circ}$ \\
\hline Xgwm186 & 5' GCAGAGCCTGGTTCAAAAAG3' & 5' CGCCTCTAGCGAGAGCTATG3' & $5 \mathrm{~A}$ & $60 \mathrm{C}^{\circ}$ \\
\hline Xgwm408 & 5' TCGATTTATTTGGGCCACTG3' & 5' GTATAATTCGTTCACAGCACGC3' & $5 \mathrm{~B}$ & $55 \mathrm{C}^{\circ}$ \\
\hline Xgwm190 & 5' GTGCTTGCTGAGCTATGAGTC3' & 5' GTGCCACGTGGTACCTTTG3' & $5 \mathrm{D}$ & $60 \mathrm{C}^{\circ}$ \\
\hline Xgwm459 & 5' ATGGAGTGGTCACACTTTGAA3' & 5' AGCTTCTCTGACCAACTTCTCG3' & $6 \mathrm{~A}$ & $55 \mathrm{C}^{\circ}$ \\
\hline Xgwm626 & 5' GATCTAAAATGTTATTTTCTCTC3' & 5' TGACTATCAGCTAAACGTGT3' & $6 \mathrm{~B}$ & $50 \mathrm{C}^{\circ}$ \\
\hline Xgwm325 & 5' TTTCTTCTGTCGTTCTCTTCCC3' & 5' TTTTTACGCGTCAACGACG3' & $6 \mathrm{D}$ & $60 \mathrm{C}^{\circ}$ \\
\hline Xgwm63 & 5' TCGACCTGATCGCCCCTA3' & 5' CGCCCTGGGTGATGAATAGT3' & $7 \mathrm{~A}$ & $60 \mathrm{C}^{\circ}$ \\
\hline Xgwm577 & 5' ATGGCATAATTTGGTGAAATTG3' & 5' TGTTTCAAGCCCAACTTCTATT3' & $7 \mathrm{~B}$ & $55 \mathrm{C}^{\circ}$ \\
\hline Xgwm437 & 5' GATCAAGACTTTTGTATCTCTC3' & 5' GATGTCCAACAGTTAGCTTA3' & $7 \mathrm{D}$ & $50 \mathrm{C}^{\circ}$ \\
\hline
\end{tabular}

\section{Statistical analysis:}

All statistical analysis performed using SAS 9.3 (2011) statistical software including analysis of variance (ANOVA), principal component analysis (PCA). Consequently, genotypes $\mathrm{x}$ trait biplot (GT biplot) constructed to differentiate between the studied cultivars based on the morphological characters. Variability for each locus was estimated using polymorphism information content value (PIC). PIC for SSR markers was calculated according to Anderson et al., 1993. Marker index (MI) was calculated according to Powell et al., 1996. Similarity matrix was computed (Jaccard coefficient) computed for each of the used markers leading to dendrogram using unweighted pair group method arithmetic mean (UPGMA). Single marker analysis was done based on simple linear regression (Pearson coefficient) was computed to find the correlation between each morphological character and individual markers.

\section{Results and Discussion:}

\section{(i) Phenotypic characterizations:}

The analysis of variance (Table 4) showed significant or highly significant differences between the studied cultivars under investigation and insignificant differences only in case of F. CL, Ped. L, and Ear Dens. The variance of the interaction between genotypes and years (GxY) was significant and highly significant in most characters and insignificant in case of F.L.AT, Ear Dens, and Out. GL. Pub. These findings can be attributed to that the most of the morphological characters are controlled by epistatic and pleiotropic genes effects (Zarkiti et al. 2010). The insignificance of the interaction between genotypes and years $(\mathrm{GxY})$ was found in Out. Gl. Pub can be attributed to its monogenic inheritance (Feltaous et al., 2014) which in turn reflected by less influences by environment factors, in the same manner F. L. AT (Isidro et al., 2012). 
Website: www.aun.edu.eg/faculty_agriculture/journals_issues_form.php E-mail:ajas@aun.edu.eg

Table 4. Analysis of variance (ANOVA) for the studied morphological characters.

\begin{tabular}{|l|c|c|c|c|c|c|c|c|c|c|}
\hline \multirow{2}{*}{ S.O.V } & \multirow{2}{*}{ D.F } & \multicolumn{9}{|c|}{ Mean squares } \\
\cline { 3 - 11 } & & G. H & F. CL & HR. AR & CL. AR & F. L. AT & W. SH & W. BL & W. Ear & W. Ped \\
\hline Year (Y) & 1 & $2.33^{\text {NS }}$ & $15.49^{\text {NS }}$ & $6.86^{*}$ & $23.05^{*}$ & $0.76^{\text {NS }}$ & $15.42^{* *}$ & $0.76^{\text {NS }}$ & $10.71^{* *}$ & $21.00^{* *}$ \\
\hline Rep (R) & 2 & $2.05^{\text {NS }}$ & $2.29^{\text {NS }}$ & $3.00^{\text {NS }}$ & $7.05^{\text {NS }}$ & $4.90^{*}$ & $10.33^{* *}$ & $5.90^{*}$ & $0.19^{\text {NS }}$ & $0.62^{\text {NS }}$ \\
\hline Genotypes (G) & 13 & $2.17^{*}$ & $8.04^{\text {NS }}$ & $3.37^{* *}$ & $13.44^{* *}$ & $4.69^{* *}$ & $7.98^{* *}$ & $4.82^{* *}$ & $4.35^{* *}$ & $7.81^{* *}$ \\
\hline GxY & 13 & $3.46^{* *}$ & $4.76^{* *}$ & $4.6^{* *}$ & $8.28^{*}$ & $1.27^{\text {NS }}$ & $4.35^{* *}$ & $8.15^{* *}$ & $5.99^{* *}$ & $2.94^{*}$ \\
\hline Error & 54 & 1.16 & 4.26 & 1.12 & 4.28 & 1.50 & 1.25 & 1.36 & 1.38 & 1.56 \\
\hline C.V & & 31.61 & 60.21 & 20.05 & 62.08 & 49.42 & 19.87 & 25.00 & 25.00 & 21.74 \\
\hline
\end{tabular}

Continued Table 4:

\begin{tabular}{|l|c|c|c|c|c|c|c|c|c|}
\hline \multirow{2}{*}{ S.O.V } & \multirow{2}{*}{ D.F } & \multicolumn{7}{|c|}{ Mean squares } \\
\cline { 3 - 10 } & & F. L. W & F. L. L & Ped. L & PL. HT & $\begin{array}{c}\text { Out. Gl. } \\
\text { Pub }\end{array}$ & $\begin{array}{c}\text { Ear. } \\
\text { Dens. }\end{array}$ & $\begin{array}{c}\text { Ear. } \\
\text { Orint. }\end{array}$ & $\begin{array}{c}\text { Ear } \\
\text { shape }\end{array}$ \\
\hline Year (Y) & 1 & $15.42^{* *}$ & $6.8^{*}$ & $0.19^{\mathrm{NS}}$ & $0.05^{\mathrm{NS}}$ & $3.8^{\mathrm{NS}}$ & $4.76^{*}$ & $1.19^{\mathrm{NS}}$ & $0.19^{\mathrm{NS}}$ \\
\hline Rep (R) & 2 & $0.19^{\mathrm{NS}}$ & $7.05^{* *}$ & $0.76^{\mathrm{NS}}$ & $0.05^{\mathrm{NS}}$ & $2.71^{\mathrm{NS}}$ & $5.91^{* *}$ & $0.90^{\mathrm{NS}}$ & $6.62^{*}$ \\
\hline Genotypes (G) & 13 & $6.23^{* *}$ & $16.70^{* *}$ & $3.94^{\mathrm{NS}}$ & $3.33^{* *}$ & $7.46^{* *}$ & $1.48^{\mathrm{NS}}$ & $6.64^{* *}$ & $15.32^{*}$ \\
\hline G*Y & 13 & $4.35^{* *}$ & $1.11^{\mathrm{NS}}$ & $7.57^{* *}$ & $1.69^{*}$ & $0.78^{\mathrm{NS}}$ & $1.48^{\mathrm{NS}}$ & $2.63^{*}$ & $13.52^{* *}$ \\
\hline Error & 54 & 1.18 & 1.32 & 2.14 & 0.79 & 1.08 & 1.11 & 1.30 & 1.53 \\
\hline C.V & & 13.25 & 17.35 & 24.02 & 14.73 & 23.14 & 17.32 & 22.07 & 39.99 \\
\hline
\end{tabular}

Where: NS, ${ }^{*}, *$ are none-significant, significant and highly significant at 0.05 and 0.01 probability, respectively.

Principal component analysis (PCA) is a multivariate technique computed to estimate genetic variability. PCA works on basis of reducing the number of variables contributing to the variability between the studied cultivars. Simple statistics calculated included mean and standard deviation. Correlation matrix was calculated, where, its score was used to calculate eigenvalues consequently eigenvectors values which is used in PCA analysis. PCA results (Table 5) indicated that PC1 and PC2 scored $32.88 \%$ and $16.43 \%$, respectively. The first two components explained $49.31 \%$ of the total variation. PC1 was found to be more related to W. Ped, W. Ear, W. BL, W. SH, and F. CL. similarly, PC2 was more related to F. L. L, Ped. L, PL. HT and F. L. AT (Table 4).
Table 5. Principal component (PC1 and PC2) for morphological characters.

\begin{tabular}{|l|c|c|}
\hline \multicolumn{1}{|c|}{ Characters } & PC1 & PC2 \\
\hline G. H & -0.089 & -0.171 \\
\hline F. CL & 0.219 & 0.027 \\
\hline HR. AR & 0.193 & -0.205 \\
\hline CL. AR & -0.109 & -0.369 \\
\hline F. L. AT & -0.285 & 0.292 \\
\hline W. SH & 0.365 & -0.122 \\
\hline W. BL & 0.377 & 0.071 \\
\hline W. Ear & 0.390 & -0.098 \\
\hline W. Ped & 0.382 & -0.134 \\
\hline F. L. W & 0.141 & 0.304 \\
\hline F. L. L & -0.047 & 0.449 \\
\hline Ped. L & 0.015 & 0.343 \\
\hline PL. HT & 0.201 & 0.294 \\
\hline Out. Gl. Pub & 0.177 & 0.046 \\
\hline Ear Dens & 0.267 & -0.046 \\
\hline Ear Orint & 0.221 & 0.119 \\
\hline Ear shape & -0.160 & -0.378 \\
\hline \% of variance & 32.88 & 16.43 \\
\hline \% of Cumulative variance & 32.88 & 49.31 \\
\hline
\end{tabular}


Genotyping by Trait biplot:

GT biplot is a powerful informative graphical technique either for clustering and grouping the genotypes or displaying the interrelation among the studied characters in genetic variability (Malik et al., 2013). PC1 scores plotted against PC2 scores for each genotype and each character as shown in Figure 1. GT biplot explained $49.31 \%$ of the total variation. The long vectors are the most discriminating characters in the variation. The most discriminating characters between the studied cultivars are CL. AR, F. L. AT, F. L. L., Ped. L, Ear shape, HR. AR and waxiness characters where it placed in long vectors. The vectors of waxiness of all plant parts are long vectors where it showed high variability for these characters in the studied Egyptian cultivars, these findings are in harmony with these obtained by Malik et al., (2014). GT biplot grouped the cultivars under investigation into three groups as follow:

1- First group consists of Sids 12, Sids 14, Sakha 94, Sakha 95, Shandaweel 1, Gemmiza 12, Giza 171, Misr 2, and Misr 3 characterized with high waxiness in all parts of the plant.

2- Second group includes Sids 1, Giza 168, and Gemmiza 11 which is characterized by long and droopy flag leaf, and long peduncle.

3- Third group consists of cultivars Sids 13 and Sakha 93 remarked by strong coloration of auricles.

It was difficult to attribute the genotypes, placed in the same group, to its pedigree (Table 1). These findings are in harmony with those obtained by Fufa et al., (2005). Otherwise, it was easy to relate them to their morphological characters, for instance, the first group is classified as the high waxiness in all parts of plant group and the second group characterized as droopy flag leaf and long peduncle but the third group identified by their strong purple colour of auricles. GT biplot graphic as a tool for displaying the correlation between the studied characters can be interpreted as follow; the cosine of angle between two vectors determines the correlation between the characters. If angle $<90^{\circ}$ (acute) suggests a positive correlation between the characters. The angle $>90^{\circ}$ (obtuse) indicates the negative correlation between characters or incompatible characters. Angle of zero and $180^{\circ}$ suggest +1 and -1 correlation, respectively. Whereas, angle of $90^{\circ}$ indicates that there is no correlation between the characters. The results of the present study indicate that the complete correlation $(+1)$ was found between Out. Gl. Pub and W. BL. 


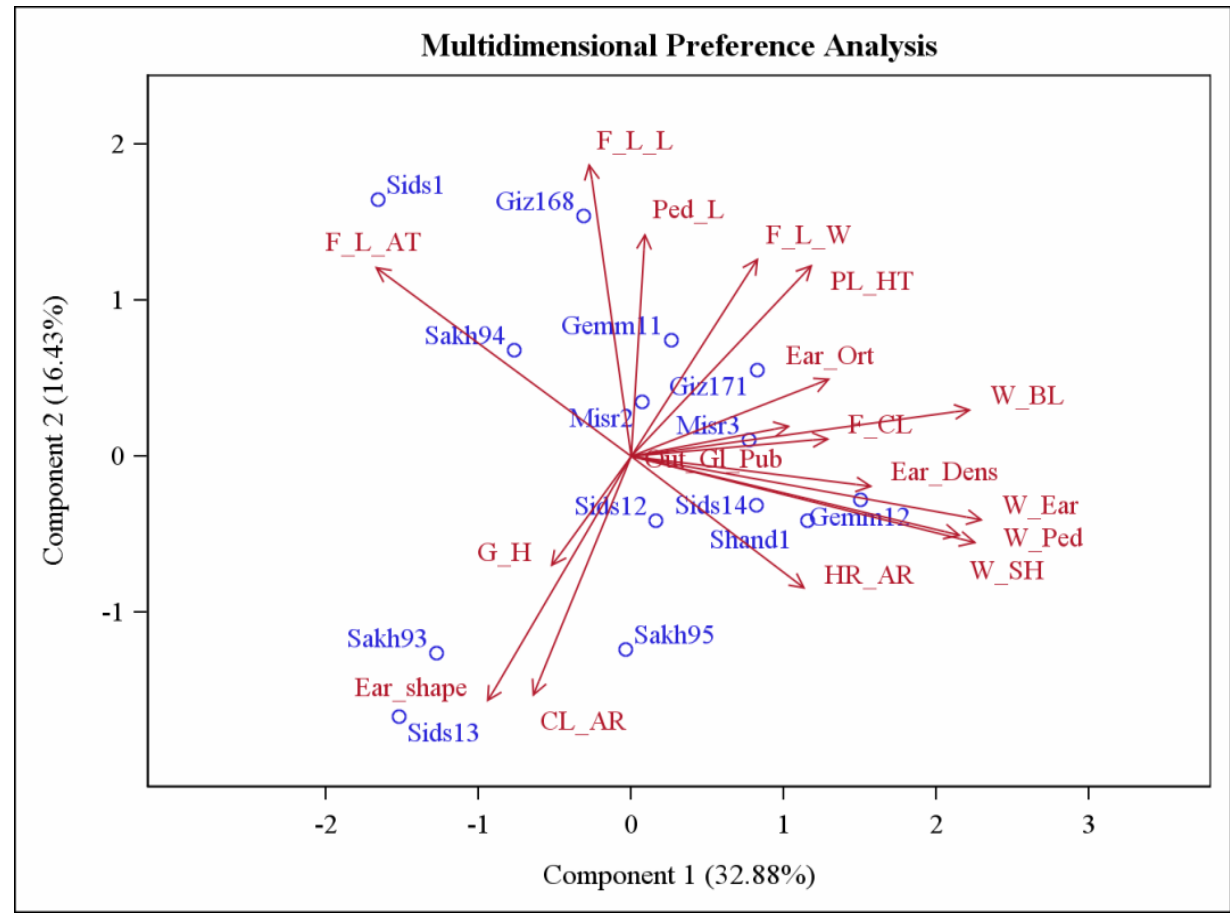

Figure 1: GT biplot for the morphological characters.

A negative correlation was found between G. H and W. SH. Also, negative correlation was found between F. L. L and between W. SH and Ped. L. The waxiness of all studied plant parts, HR. AR, F. CL, Ear Orint, and Ear Dens was found positively correlated. Waxiness was found to be incompatible characters (negative correlation) with Ped. L, F. L. AT, G. H, CL. AR, and Ear Shape. Many characters found to be incompatible characters, for example, HR. AR and PL. HT, similarly F. L. AT and F. L. W and lastly F. L. L with W. SH. Furthermore, Correlation $=-1$ was found between G. H and W. BL.

\section{(ii) Genetic characterization:}

Twenty one microsatellite data was scored as (1) for presence and (0) for absence of the produced band only the polymorphic markers are included in analysis and calculations. Th SSR markers' results indicated that total number of alleles 112 polymorphic at 21 loci with an average of 5.33 per locus (Table 6). This allele's polymorphism is lower than average obtained by Stepien et al., (2014) with 13 alleles per locus and more than alleles obtained by Salem et al., (2008) and Salem et al., (2014) with 3.2 alleles. The number of alleles ranged from 1 to 14 alleles. The maximum number of alleles was found in primer Xgwm186 with bands size of $123 \mathrm{bp}$ - $791 \mathrm{bp}$ (Figure 2 ) while, the minimum number of alleles was found in primers Xgwm190, Xgwm389 of 120 bp and 122 bp, respectively (Figure 3 ). 


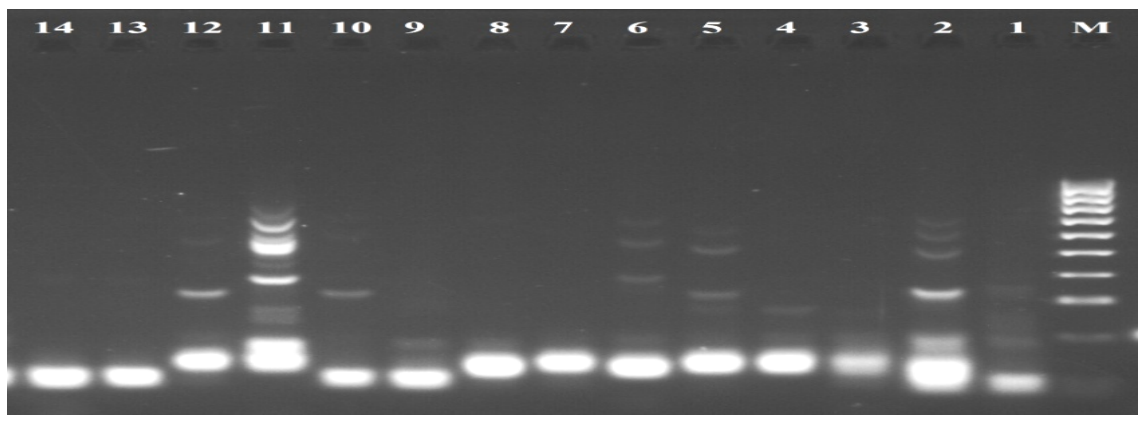

Figure 2. Amplified bands of primer Xgwm186 in the studied cultivars.

Where: $\mathbf{M}=$ ladder 100-1000 bp, $\mathbf{1}=$ Shandaweel, $\mathbf{2}=$ Sids 1, $\mathbf{3}=$ Sids 12, $\mathbf{4}=$ Sids 13, $\mathbf{5}=$ Sids 14, $\mathbf{6}=$ Giza 168, 7= Giza 171, 8= Misr 2, 9= Misr 3, 10= Sakha 93, 11= Sakha 94, 12= Sakha 95, 13= Gemmiza 11, and $\mathbf{1 4}=$ Gemmiza.

PIC and MI are statistical parameters used to estimate total utility of the maker system. The high MI and PIC values indicated the suitability of SSR markers in estimating genetic diversity. The present study results showed that PIC values varied from $0.14-0.98$ with an average 0.65 . The lowest PIC value was found in primers Xgwm190, Xgwm111 with 0.14 and the highest PIC value found in primers
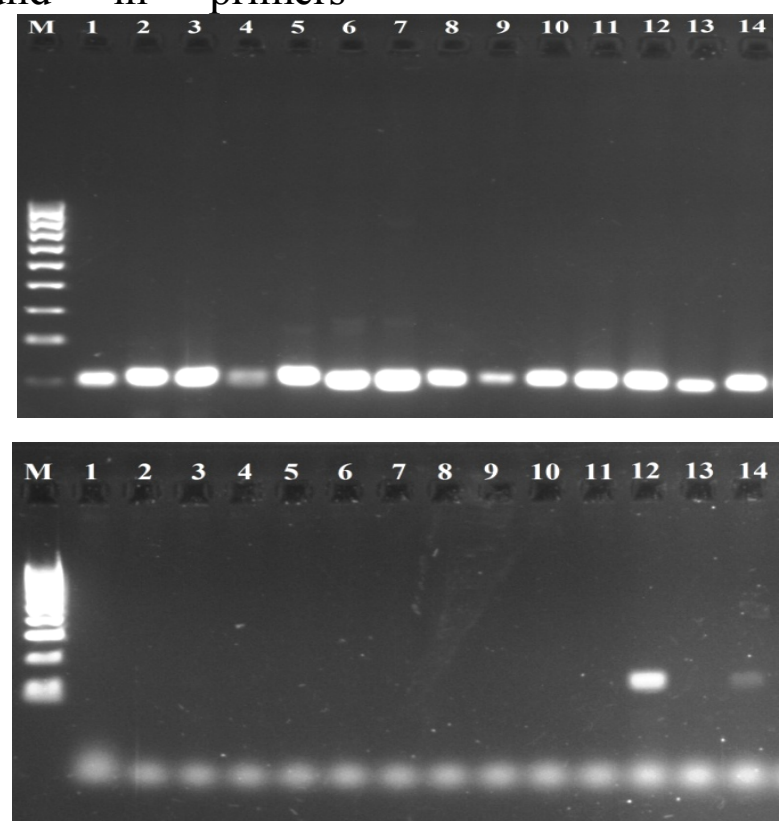

Xgwm 190
Xgwm165, Xgwm389. The results show that MI ranged from 0.14 to 13.19 with an average of 3.33 over all used markers. The highest MI value (13.19) was obtained from Xgwm186 marker and the lowest MI value observed in Xgwm190 marker. The high average values of PIC and MI is an indicator of suitability of SSR markers in determining genotypes interrelationship. 
High polymorphism found in A genome with 67 alleles and an average 9 , in the same manner, $B$ genome has 35 alleles with an average 4.6 alleles. The variability in hexaploid bread wheat mainly can be related to the diversity of these two genomes, which in can be attributed to that there are more than one origin for modern $\mathrm{A}$ and $\mathrm{B}$ genomes (Yuka et al., 2019). In the contrary, low polymorphism 18 alleles with an average 2.4 allele was found in $\mathrm{D}$ genome, these findings are in agreement with many investigators studied the diversity in the D genome (Wang et al., 2013 and Li et al., 2015). From the present study and previous investigations, it is clear that $\mathrm{D}$ genome in hexaploid wheat is less diverse than the other two genomes $\mathrm{A}$ and $\mathrm{B}$ and has low variability than $\mathrm{D}$ genome progenitor Aegilops tauschii. The low variability in modern $\mathrm{D}$ genome may be as a result of adaptation to an allopolyploid, multi-genome environment (Mirzaghaderi and Mason, 2019).

Simple linear regression (Pearson coefficient) calculated between individual character's mean with each marker showed a strong and significant correlation between particular characters and specific markers. These findings suggest these markers with specific bands linked to these particular characters (Table 7). For example, Pearson coefficient between Xgwm186, Xgwm437, Xgwm160, Xgwm63, Xgwm325 and Xgwm3 are linked to CL. AR, W. BL, W. Ear, F. L. W, Ped. L, and Ear Orint. with 123 bp, 121 bp, 197 bp, 222 bp, 135 bp and 87 bp specific bands, respectively. In some cases, one marker linked to more than one character but with different bands viz Xgwm459 linked to F. CL, out. Gl. Pub and Ear Shape with 855 bp, 237 bp and 265 bp specific bands, respectively. On the other hand, some character correlated with more than one marker viz G. H correlated with Xgwm389 and Xgwm577 with 122 bp and 252 bp specific bands, respectively.

But in the other cases, one character correlated with one marker but with more than one band like F. L. L correlated to Xgwm95 with 269 bp and $217 \mathrm{bp}$ specific bands. These findings suggest that the correlated specific markers with particular characters are candidate linked markers with these characters. These results are in agreement with Abdelsabour et al., (2019), where they reported that some SRAP markers were correlated with some agronomic traits and can be suggested as candidate linked markers to these traits.

Table 6. Number of alleles, range of bands, PIC, and MI for each SSR primer.

\begin{tabular}{|l|c|c|l|l|}
\hline Primer & No. of alleles & $\begin{array}{c}\text { Range of } \\
\text { bands }\end{array}$ & PIC & MI \\
\hline Xgwm33 & 4 & $66-159$ & 0.42 & 0.94 \\
\hline Xgwm18 & 2 & $80-350$ & 0.38 & 0.19 \\
\hline Xgwm458 & 3 & $50-232$ & 0.47 & 1.40 \\
\hline Xgwm95 & 10 & $75-776$ & 0.93 & 9.28 \\
\hline Xgwm111 & 2 & $75-121$ & 0.14 & 0.28 \\
\hline Xgwm261 & 3 & $102-216$ & 0.62 & 1.86 \\
\hline Xgwm155 & 11 & $143-1435$ & 0.57 & 0.82 \\
\hline Xgwm389 & 1 & 122 & 0.98 & 0.98 \\
\hline Xgwm3 & 4 & $44-174$ & 0.26 & 0.57 \\
\hline Xgwm160 & 2 & $117-197$ & 0.62 & 1.24 \\
\hline Xgwm513 & 3 & $128-367$ & 0.74 & 2.23 \\
\hline Xgwm165 & 2 & $60-190$ & 0.98 & 1.96 \\
\hline Xgwm186 & 14 & $123-791$ & 0.94 & 13.19 \\
\hline Xgwm408 & 8 & $53-462$ & 0.64 & 5.15 \\
\hline Xgwm190 & 1 & 120 & 0.14 & 0.14 \\
\hline Xgwm459 & 12 & $58-1164$ & 0.92 & 10.15 \\
\hline Xgwm626 & 7 & $109-1014$ & 0.85 & 5.93 \\
\hline Xgwm325 & 2 & $59-135$ & 0.94 & 0.47 \\
\hline Xgwm63 & 10 & $113-1027$ & 0.70 & 4.51 \\
\hline Xgwm577 & 9 & $73-944$ & 0.85 & 6.03 \\
\hline Xgwm437 & 2 & $92-121$ & 0.67 & 1.34 \\
\hline Total & 112 & & 13.74 & 68.65 \\
\hline Mean & 5.33 & & 0.65 & 3.27 \\
\hline
\end{tabular}


Genetic similarity matrix constructed based on primers' patterns (Jaccard coefficient) is presented in Table 8. The matrix show that similarity ranged from 0.250 to 0.620 . Where, cultivars Giza 168 and Giza 171 found to be very similar (similarity $=0.620$ ), whereas low similarity found between Shandaweel 1 and Misr 3 (0.250) with similarity aver- age of 0.414 . The similarity, dissimilarity or genetic distance matrix is very helpful for breeders in breeding programs to choose the most distant parents in crossing program (Van Becelaere et al., 2005) (Shandaweel 1 and Misr 3) and avoid using the most closed cultivars (Giza 171 and Giza 168).

Table 7. The linked markers with morphological characters based on Karl Pearson coefficient

\begin{tabular}{|l|c|c|c|c|c|}
\hline Markers & Characters & Specific bands & Pearson coefficient & P value & $\mathbf{R}^{\mathbf{2}}$ \\
\hline Xgwm389 & G. H & 122 & $0.536^{*}$ & 0.047 & 28.73 \\
\hline Xgwm577 & G. H & 252 & $0.536^{*}$ & 0.047 & 28.73 \\
\hline Xgwm459 & F. CL & 855 & $0.557^{*}$ & 0.038 & 31.02 \\
\hline Xgwm186 & CL. AR & 123 & $0.585^{*}$ & 0.028 & 34.22 \\
\hline Xgwm437 & W. BL & 121 & $0.537^{*}$ & 0.048 & 28.84 \\
\hline Xgwm160 & W. Ear & 197 & $0.627^{*}$ & 0.016 & 39.31 \\
\hline Xgwm63 & F. L. W & 222 & $0.713^{* *}$ & 0.004 & 50.84 \\
\hline Xgwm95 & F. L. L & 269 & $0.557^{*}$ & 0.039 & 31.02 \\
\hline Xgwm95 & F. L. L & 217 & $0.557^{*}$ & 0.039 & 31.02 \\
\hline Xgwm325 & Ped. L & 135 & $0.608^{*}$ & 0.021 & 36.97 \\
\hline Xgwm459 & Out. Gl. Pub & 237 & $0.697^{* *}$ & 0.006 & 48.58 \\
\hline Xgwm3 & Ear. Orint & 87 & $0.594^{*}$ & 0.025 & 35.28 \\
\hline Xgwm459 & Ear. Shape & 265 & $0.646^{*}$ & 0.013 & 41.73 \\
\hline Xgwm626 & Ear. Shape & 650 & $0.763^{*}$ & 0.002 & 58.22 \\
\hline
\end{tabular}

Where: NS, *** significant and highly significant at 0.05 and 0.01 level of probability, respectively.

Dendrogram constructed based on similarity matrix obtained from SSR markers results using unweighted Pair group method with arithmetic mean (UPGMA) showed that the studied cultivars clustered into three main clusters. The first main cluster contained Sakha 94 and Sakha 95 and the seconded main cluster divided into four subclusters. The first one contained Misr 3 and Sids 13, but Gemmiza 11 was placed in the second subcluster, whereas, Sids 14, Gemmiza 12, Sakha 93, and Sids 12 were placed in the third subcluster moreover Sids1 was placed in the fourth subcluster. In addition, the third main cluster divided into three subclusters; Misr 2 was placed in the first subcluster, second subcluster contained Giza 168 and Giza 171 and finally Shandaweel 1 was placed in the third subcluster (Figure 4). 


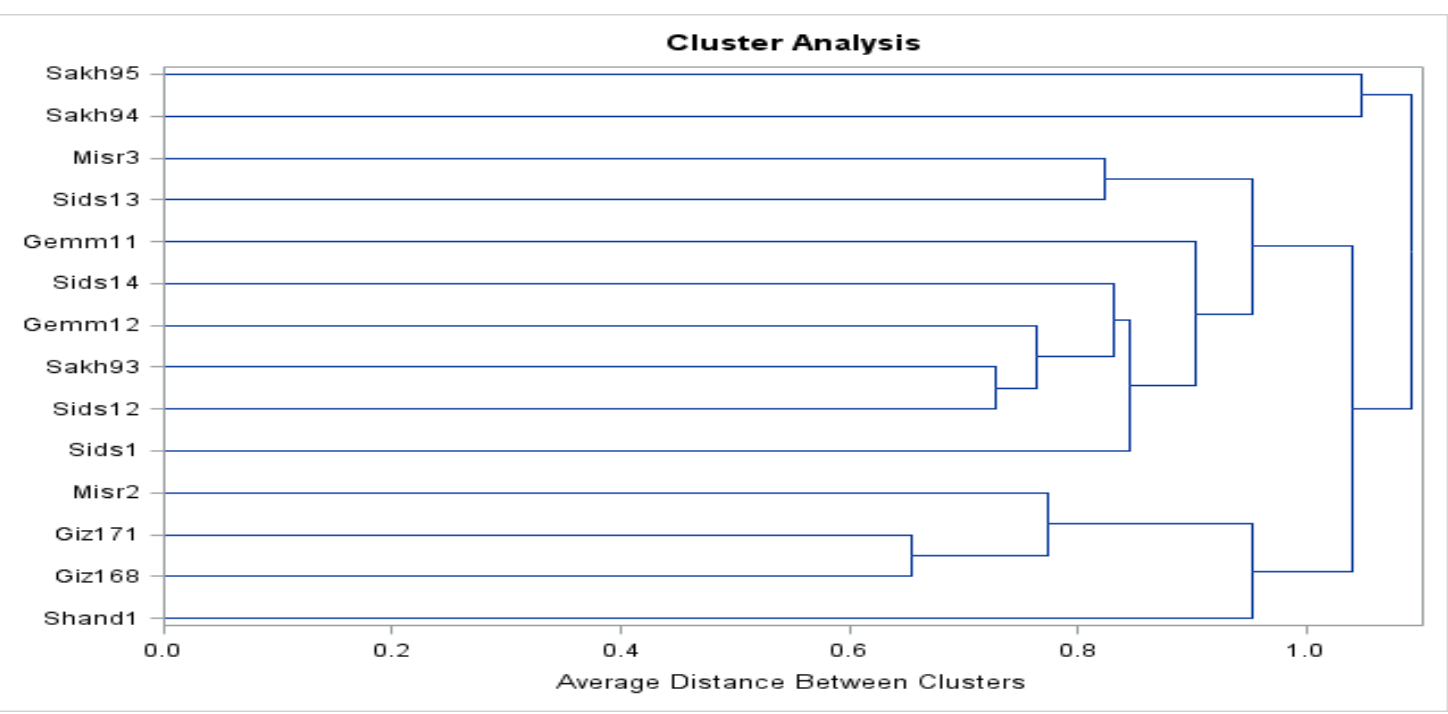

Figure 4: Dendrogram for average genetic distance based on SSR similarity matrix.

The cultivars similarity (\%) based on morphological characters (Table 8) ranged from 82.22 up to 93.74. The highest similarity (93.74) was found between Sids 12 and Sids 14 but the lowest similarity (82.22) was found between Sids 1 and Misr 3 . The range of similarity based on morphological characters is very small where it is hard to distinguish between the cultivars. Moreover, the similarity matrix based on SSR markers (Table 9) ranged from 0.250 up to 0.620 ; the lowest similarity $(0.250)$ was found between Shandaweel 1 and Misr 3 while the highest similarity (0.620) was found between Giza 171 and Giza 168. The results revealed that there are differences between similarity based on morphological and SSR markers due to the environmental factors and its pleiotropic inheritance, but in case of molecular markers it depends on DNA polymorphism, not influenced by environmental conditions, and cover large proportion of wheat genomes. The similarity based SSR markers give a clear cut distinguishing between studied cultivars with a high similarity range between the cultivars than the similarity based on morphological characters.

The present study results show that a small number of SSR markers are suitable to estimate genetic diversity, even between the closely related cultivars because it covers a large portion of genome and does not influence by environmental factors. The statistical parameters e.g. similarity coefficient, PIC, MI, number of alleles are effective indices in estimating markers variability, as reported in wheat by many investigators e.g. Zarkti et al., 2010, Fatima et al., 2016, Mehraj et al., 2019. For more extend these specific SSR markers which are linked to particular characters can be used as candidate markers in marker assisted selection (MAS). It can be helpful for breeders planning for crossing program.

\section{Acknowledgment:}

The author would like to thank the Department of Genetics - Faculty of Agriculture - Assiut University for permission to use the equipment of the biotechnology laboratory. 
Table 8. Jaccard's similarity coefficient (\%) among the studies cultivars based on morphological characters:

\begin{tabular}{|l|c|c|c|c|c|c|c|c|c|c|c|c|c|}
\hline Genotypes & Shandawee & Sids & Sids & Sids & Sids & Giza & Giza & Misr & Misr & Sakha & Sakha & Sakha & Gemmiza 11 \\
\hline Sids 1 & 82.72 & & & & & & & & & & & & \\
\hline Sids 12 & 88.70 & 83.56 & & & & & & & & & & & \\
\hline Sids 13 & 84.78 & 83.66 & 84.20 & & & & & & & & & & \\
\hline Sids 14 & 90.84 & 82.60 & 93.74 & 83.64 & & & & & & & & & \\
\hline Giza 168 & 88.68 & 86.59 & 88.96 & 84.37 & 87.49 & & & & & & & & \\
\hline Giza 171 & 90.23 & 84.67 & 90.70 & 82.88 & 91.44 & 89.87 & & & & & & & \\
\hline Misr 2 & 89.81 & 85.79 & 89.83 & 86.36 & 90.99 & 90.55 & 92.63 & & & & & & \\
\hline Misr 3 & 88.28 & 82.22 & 90.58 & 82.91 & 91.74 & 87.73 & 93.04 & 91.38 & & & & & \\
\hline Sakha 93 & 85.08 & 85.73 & 89.17 & 89.75 & 85.14 & 85.49 & 85.19 & 85.91 & 85.72 & & & & \\
\hline Sakha 94 & 85.55 & 87.95 & 90.79 & 86.44 & 90.37 & 90.73 & 90.87 & 92.39 & 91.18 & 87.66 & & & \\
\hline Sakha 95 & 87.91 & 83.91 & 91.39 & 87.85 & 91.73 & 87.35 & 89.47 & 92.19 & 91.78 & 90.41 & 89.94 & & \\
\hline Gemmiza & 90.02 & 88.12 & 92.48 & 83.83 & 90.47 & 93.09 & 92.88 & 92.04 & 91.24 & 87.02 & 89.86 & 90.84 & \\
\hline Gemmiza & 91.06 & 82.50 & 88.50 & 83.13 & 93.06 & 85.86 & 90.92 & 90.46 & 91.21 & 83.00 & 86.72 & 90.01 & 89.17 \\
\hline
\end{tabular}

Table 9. Jaccard's similarity coefficient (\%) among the studies cultivars based on SSR markers

\begin{tabular}{|l|c|c|c|c|c|c|c|c|c|c|c|c|c|}
\hline Genotypes & Shandaweel & Sids & Sids & Sids & Sids & Giza & Giza & Misr & Misr & Sakha & Sakha & Sakha & Gemmiza \\
\hline Sids 1 & 0.367 & & & & & & & & & & & & \\
\hline Sids 12 & 0.317 & 0.480 & & & & & & & & & & & \\
\hline Sids 13 & 0.328 & 0.469 & 0.527 & & & & & & & & & & \\
\hline Sids 14 & 0.339 & 0.489 & 0.547 & 0.429 & & & & & & & & & \\
\hline Giza 168 & 0.520 & 0.449 & 0.509 & 0.350 & 0.411 & & & & & & & & \\
\hline Giza 171 & 0.453 & 0.500 & 0.448 & 0.464 & 0.429 & 0.620 & & & & & & & \\
\hline Misr 2 & 0.385 & 0.396 & 0.362 & 0.426 & 0.364 & 0.490 & 0.604 & & & & & & \\
\hline Misr 3 & 0.250 & 0.404 & 0.438 & 0.500 & 0.467 & 0.391 & 0.452 & 0.417 & & & & & \\
\hline Sakha 93 & 0.440 & 0.489 & 0.549 & 0.426 & 0.471 & 0.490 & 0.453 & 0.440 & 0.393 & & & & \\
\hline Sakha 94 & 0.314 & 0.442 & 0.396 & 0.412 & 0.346 & 0.340 & 0.358 & 0.367 & 0.290 & 0.396 & & & \\
\hline Sakha 95 & 0.264 & 0.348 & 0.345 & 0.358 & 0.458 & 0.291 & 0.358 & 0.367 & 0.311 & 0.426 & 0.348 & & \\
\hline Gemmiza & 0.290 & 0.389 & 0.450 & 0.371 & 0.456 & 0.355 & 0.417 & 0.356 & 0.431 & 0.481 & 0.339 & 0.293 & \\
\hline Gemmiza & 0.296 & 0.477 & 0.510 & 0.415 & 0.460 & 0.423 & 0.442 & 0.400 & 0.383 & 0.556 & 0.413 & 0.413 & 0.529 \\
\hline
\end{tabular}

\section{References:}

Abdelsabour, G.A.K., G.A.R. El-Sherbeny and H.M.A. Elsayed (2019). Three SRAP molecular markers linked to yield component traits in wheat. Asian J. Res. and Rev. Agric. 1(1): 25-35.

Anderson, J.A., G.A. Churchill, J.E. Antrique, S.D. Tanksley and M.E. Sorrels (1993). Optimizing parental selection for genetic linkage maps. Genome 36: 181-188.

Biochemical and Molecular Techniques (BMT), UPOV 2004. https://www.upov.int/meetings/en/details.jsp?meeting_id=7344

FAO STAT 2017a. http://www.fao.org/faostat/en/\#data/QC

FAO STAT 2017b. http://www.fao.org/giews/countrybrief/country.jsp?code=EGY

Fatima, Henkrar, Jamal El-Haddoury, Hassan Ouabbou, Nasserlehaq Nsarellah, Driss Iraqi, Najib Bendaou and Sripada Mahabala Udupa (2016). Genetic diversity reduction in improved durum wheat cultivars of Morocco as revealed by microsatellite markers. Sci. Agric. 73(2): 134-141.

Feltaous, Y.M., Puja Srivastava, Achla Sharma and NS Bains (2014). Inheritance of some qualitative traits in triticale $\mathrm{X}$ wheat crosses. Proceedings of National Sym- 
posium on "Crop Improvement for Inclusive Sustainable Development", Punjab Agricultural University, Ludhiana, India on 7-9 November 2014.

Fufa, H., P. Baenziger,B. S. Beecher, I. Dweikat, R.A. Graybosch, and K. Eskridge (2005). Comparison of phenotypic and molecular marker-based classifications of hard red winter wheat cultivars. Euphytica 145: 133-146. DOI: 10.1007/s10681005-0626-3.

Isidro, J., R. Knox, F. Clarke, A. Singh, R. De Pauw and J. Clarke (2012). Quantitative genetic analysis and mapping of leaf angle in durum wheat. Planta. 236(6):171323

Kahrizi, D., K. Cheghamirza, M. Kakaei, M. Mohammdi and E. Ebadi (2010). Heritability and genetic gain of some morpho-physiological variables of durum wheat (Triticum turgidum var. durum). African J. Biotechnol 9: 4687-4691.

Li, L.F., B. Liu, K.M. Olsen and J.F. Wendel (2015). A re-evaluation of the homoploid hybrid origin of Aegilops tauschii, the donor of the wheat D sub genome. New Phytol 208:4-8.

Malik, R., H. Sharma, A. Verma, S. Kundu, I. Sharma and R. Chatrath (2013). Hierarchical clustering of Indian wheat varieties using morphological diversity assessment. Indian J. Agric. Res. 47(2): 116-123.

Malik, R., Hemani Sharma, Indu Sharma, Sushila Kundu, Ajay Verma, Sonia Sheoran, Rajendra Kumar and Ravish Chatrath (2014). Genetic diversity of agromorphological characters in Indian wheat varieties using GT biplot. A.J.C.S. 8(9): 1266-1271.

Mehraj, Abbasov, Naib Aminov, Sevda Babayeva, Elchin Hajiyev, Robert Brueggeman, David Bedoshvili, John Raupp, Thomas Gross, Vusala Izzatullayeva, Khanbala Rustamov, Zeynal Akparov, Patrick Gross, Sevinj A. Mammadova and Bikram S. Gill (2019). Genetic diversity of Aegilops L. species from Azerbaijan and Georgia using SSR markers. Genet. Resour. Crop Evol. 66:453-463.

Mirzaghaderi, G. and A.S. Mason (2019). Broadening the bread wheat D genome. Theoretical and Applied Genetics 132:1295-1307.

Noli, E., M. S. Teriaca, M. C. Sanguineti and S. Conti (2008). Utilization of SSR and AFLP markers for the assessment of distinctness in durum wheat. Mol Breeding 22: 301313.

Poresbski, S.L., G. Bailey and R. B. Baum (1997). Modification of CTAB DNA extraction protocol for plants containing high polysaccharide and polyphenol components. Plant Mol. Biol. Reporter. 12: 8-15.

Powell, W., M. Morgante, C. Andre, M. Hanafey, J. Volgel, S. Tingey and A. Rafalskia (1996). The utility of RFLP, RAPD, AFLP and SSR (microsatellite) markers for germplasm analysis. Mol. Breed. 2: 225-238.

Osama, O. Saleh, Nahla Hamiedeldin, Ahmed F. Khafaga and Rashad M. Shoaib (2016). Molecular and morpho-anatomical characterization of some Egyptian wheat cultivars/Lines. Pak. J. Bot. 48(5): 1979-1988.

Salem, K. F. M., A. M. El-Zanaty and R. M. Esmail (2008). Assessing wheat (Triticum aestivum L.) genetic diversity using morphological characters and microsatellite markers. World J. Agri Sci 4: 538-544.

Salem, K.F.M., Marion S. Roder and Andreas Borner (2015). Assessing genetic diversity of Egyptian hexaploid wheat (Triticum aestivum L.) using microsatellite markers. Genet. Resour. Crop Evol. 62 (2): 377-385.

SAS Institute, Inc., Cary, NC, USA 2011. 
Website: www.aun.edu.eg/faculty_agriculture/journals_issues_form.php E-mail: ajas@aun.edu.eg

Stepien, L., V. Mohler, J. Bocianowski and G. Koczyk (2014). Assessing genetic diversity of Polish wheat (Triticum aestivum) varieties using microsatellite markers. Genet. Resour. Crop Evol. 54:1499-1506.

Tasnuva, S., M. Hasanuzzaman, G. Faruq, F. Sharmeen and M. Arifuzzaman (2010). Study on Differentiation of Wheat Varieties Through Morphological and Molecular Approaches. Int. J. Sustain. Crop Prod. 5(3): 29-34.

UPOV Convention (1961). https://www.upov.int/edocs/tgdocs/en/tg003.pdf.

Van Becelaere, G., E.L. Lumbbers, A.H. Paterson and P.W. Chee (2005). Pedigree-vs. DNA marker-based genetic similarity estimates in cotton. Crop Science 45(6): 2281-2287.

Wang, J, M.C. Luo, Z. Chen, F.M. You, Y. Wei, Y. Zheng and J. Dvorak (2013). Aegilops tauschii single nucleotide polymorphisms shed light on the origins of wheat $\mathrm{D}$ genome genetic diversity and pinpoint the geographic origin of hexaploid wheat. New Phytol. 198:925-937.

Yuka, Miki, Kentaro Yoshida, Nobuyuki Mizuno, Shuhei Nasuda, Kazuhiro Sato and Shigeo Takumi (2019). Origin of wheat B-genome chromosomes inferred from RNA sequencing analysis of leaf transcripts from section Sitopsis species of $\mathrm{Ae}$ gilops. DNA Research 26(2): 171-182.

Zarkti, H., H. Ouabbou, A. Hilali and S.M. Udupa (2010). Detection of genetic diversity in Moroccan durum wheat accessions using agro-morphological traits and microsatellite markers. African Journal of Agricultural Research 5(14): 1837-1844. 
التباين الوراثى بين بعض أصناف قمح الخبز المصريه باستخدام المعلمات الجزيئيه و الصفات المورفولوجيه

\section{يوسف محسن فلتاؤوس}

قسم بحوث القمح ـ معهد بحوث المحاصيل الحقليه ــمركز الحوث الزر اعيه

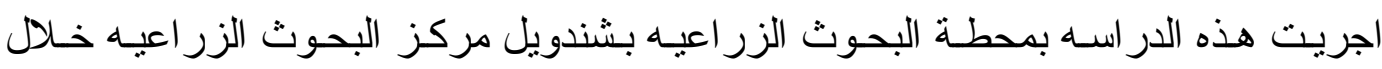

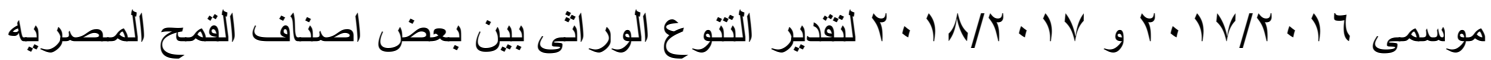

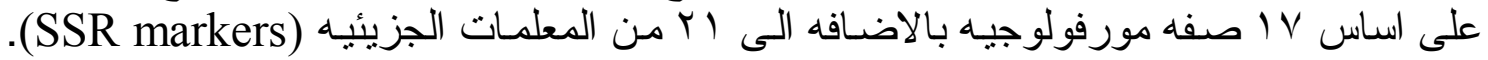

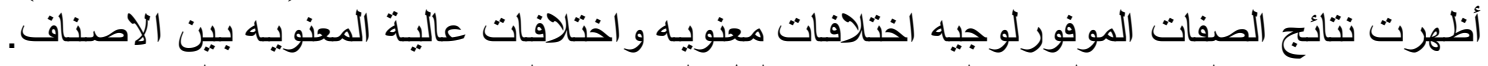

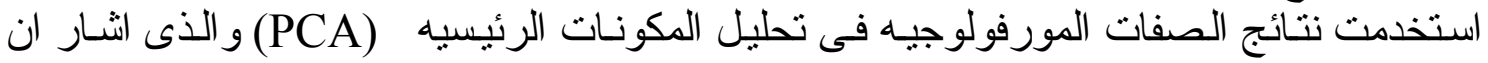

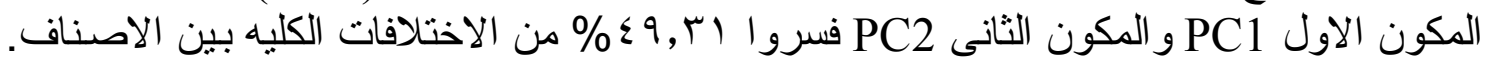

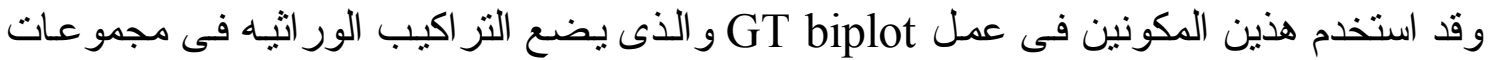

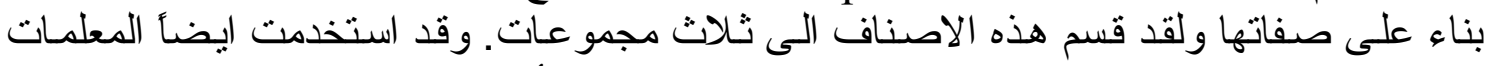

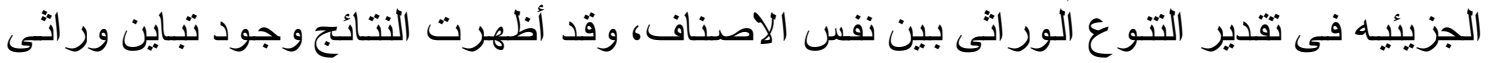

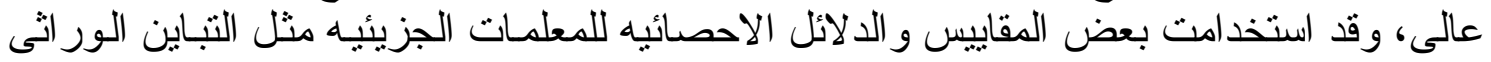

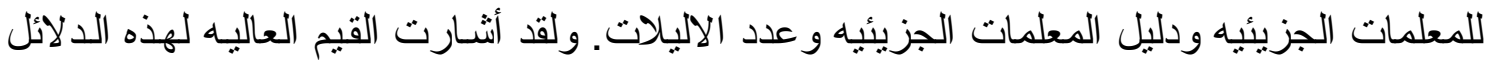

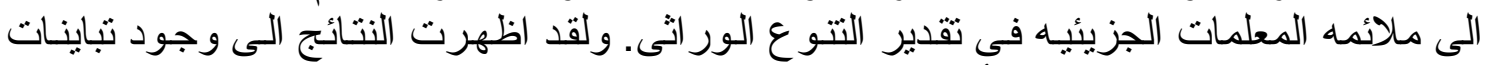

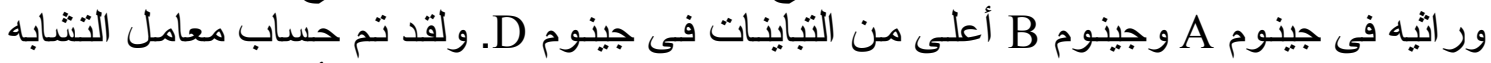

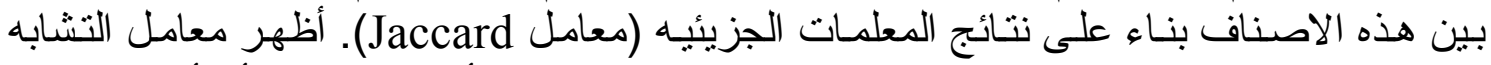

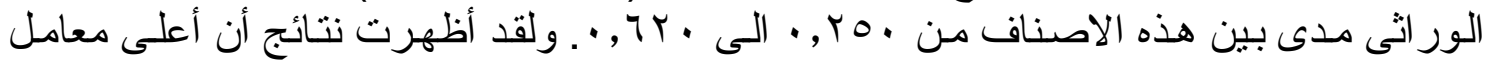

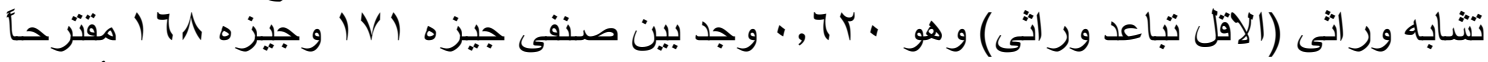

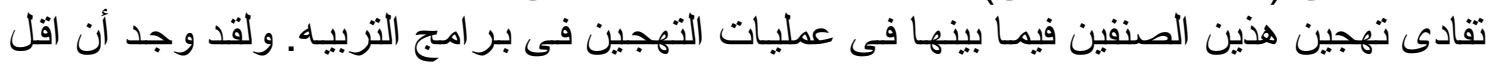

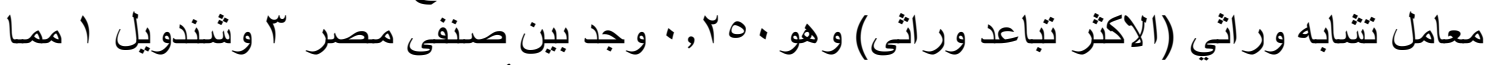

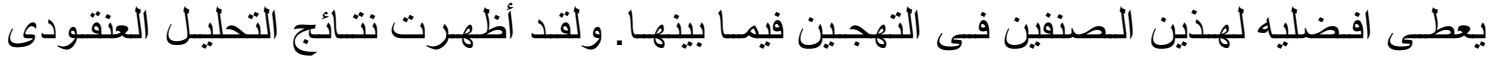

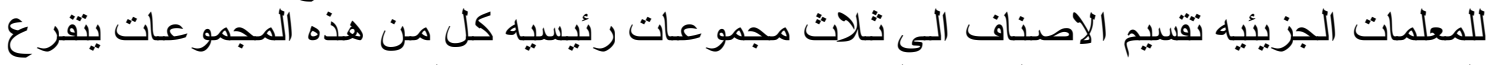

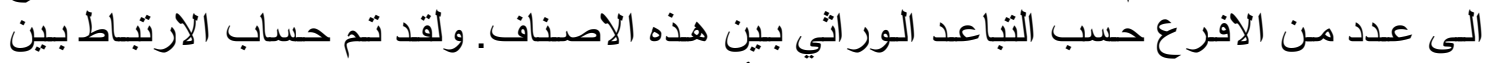

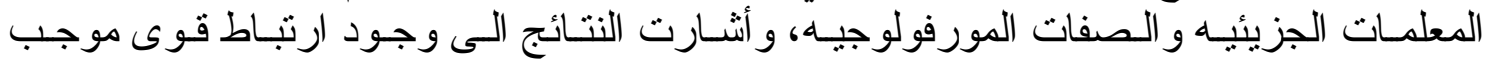

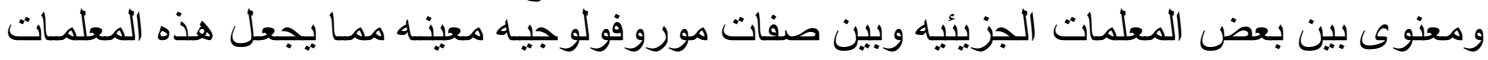

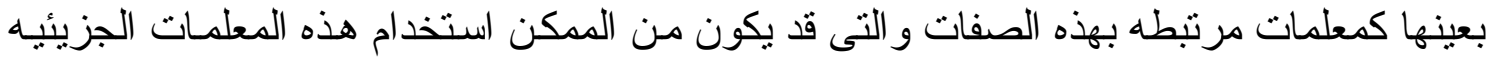

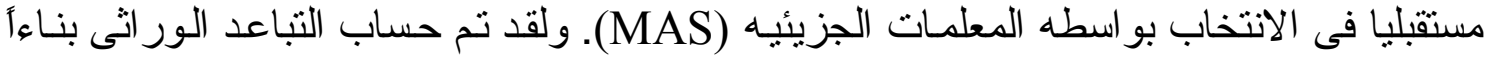

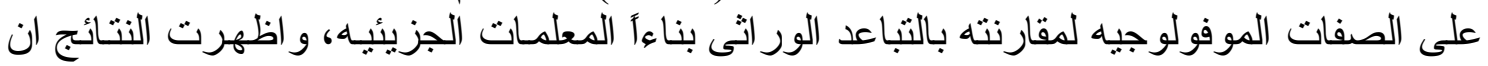

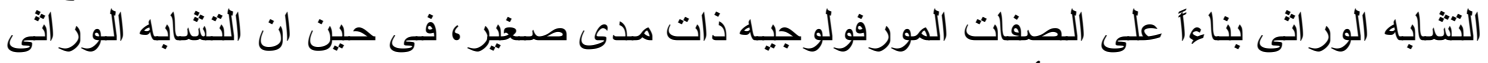

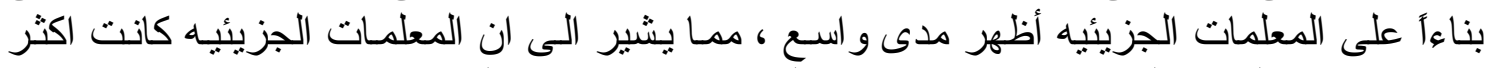

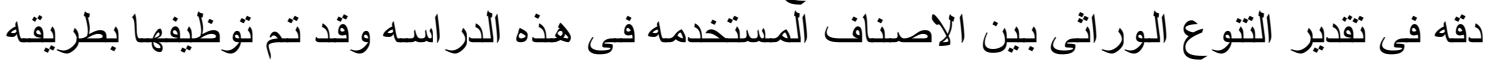

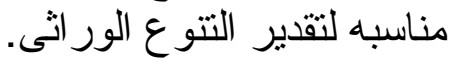

